\section{Effects of Type of Explant and Dark Preconditioning on Bud Formation in Habenaria radiata (Thunb.) in Vitro}

\author{
Kazuhiko Mitsukuri, Takaya Arita, Masahumi Johkan, \\ Satoshi Yamasaki, Kei-ichiro Mishiba, and Masayuki Oda ${ }^{\mathbf{1}}$ \\ Graduate School of Agricultural and Biological Sciences, Osaka Prefecture \\ University, Gakuenn-cho, Sakai, Osaka 599-8531, Japan
}

Additional index words. adventitious bud, browning, floret culture, micropropagation, Orchidaceae, shoot apex culture

\begin{abstract}
Habenaria radiata is a terrestrial orchid with beautiful bird-shaped petals. The wild $H$. radiata population has been severely affected by environmental disruption and overexploitation. In micropropagation of $\boldsymbol{H}$. radiata, although aseptic germination has been studied, tissue culture methods have not yet been established. Shoot apexes and leaf explants from vegetative plants and flower stalks, stolons, and floret explants from reproductive plants were chosen for this study. Explants were cultured on half-strength inorganic salts and full-strength vitamins of Murashige and Skoog (1/2 MS) medium containing $30 \mathrm{~g} \cdot \mathrm{L}^{-1}$ sucrose, $8 \mathrm{~g} \cdot \mathrm{L}^{-1}$ agar (pH 5.6) supplemented with $4.44 \mu \mathrm{M} \mathrm{N}^{6}$ benzyladenine, and $0.54 \mu M \alpha$-naphthaleneacetic acid. After 8 weeks of culture, the highest survival rate was obtained with floret explants excised from plants at the reproductive phase. In floret culture, the number of adventitious bud formation per explant was 5.4 per upper floret and 4.0 per lower floret. Dark preconditioning, which inhibited browning and contamination, of explants before shoot apex culture increased survival rates of explants (53\%) and bud formation (83\%). Consequently, a tissue culture method using florets and shoot apexes as explant material was established for $\mathrm{H}$. radiata.
\end{abstract}

Habenaria radiata (Thunb.) K. Spreng. is a terrestrial orchid found in the wetlands of Honshu, Shikoku, and Kyushu Islands in Japan. This orchid is a valuable ornamental plant because of its beautiful bird-shaped petals (Fig. 1). However, wild $H$. radiata populations have been greatly reduced by environmental disruption and overexploitation. This species, therefore, is listed in the Red Data Book of Japan (Environment Agency of Japan, 2000) as an endangered species.

Orchid seeds scarcely germinate in the field because they do not contain enough reserve nutrients or are unable to metabolize them rapidly (Rasmussen, 1995). Given their low germination rate, orchid plants are primarily propagated by in vitro seed germination (Knudson, 1922). This technique has also been applied to H. radiata (Nagashima, 1993; Takahashi et al., 2000, 2008). However, seed germination is not suitable for multiplication of elite clones based on their heterogeneity. Now, vegetative propagation using tubers is the main multiplication method for elite clones of $H$. radiata. This method has a low propagation efficiency, only two or three multiplications per year, so an alternative method is required to meet the market demand.

Micropropagation of orchid plants has been studied extensively, and mericlones of

\footnotetext{
Received for publication 5 Nov. 2008. Accepted for publication 6 Jan. 2009.

${ }^{1}$ To whom reprint requests should be addressed; e-mailmoda@plant.osakafu-u.ac.jp.
}

Cymbidium (Morel, 1960), Cattleya (Reinert and Mohr, 1967), Dendrobium (Kim et al., 1970; Roy et al., 2007), Phalaenopsis (Tanaka, 1987), and Vanda (Malabadi et al., 2004; Seeni and Latha, 2000) species have been successfully produced. Various plant parts have been used for tissue culture: stem, leaf, floret, and flower stalk (Arditti, 2008). However, only one study has reported $H$. radiata shoot apex culture (Matsui et al., 1976), and no tissue culture methods using other explant parts have been established.

In previous studies, $H$. radiata tissue cultures were contaminated with bacteria. In Cyclamen tissue culture, dark preconditioning controlled endogenous bacteria, which increased the survival rate of explants and the number of buds per explant (Ando and Murasaki, 1983; Karam and Al-Majathoub, 2000; Murasaki and Tsurushima, 1988).

In tissue culture, browning of the explants reduces regeneration and bud formation. Severe browning was also observed in tissue cultures of $H$. radiata. In our experience, dark preconditioning of explants decreased the amount of browning compound exuded from explants of Neofinetia falcata (Mitsukuri et al., 2009). In leaf cultures of apple Malus pumila Mill. (Wang et al., 1994), axillary bud cultures of guava Psidium guajava L. (Meghwal et al., 2001), and shoot apex culture of mango Mangifera indica L. (Sharma and Singh, 2002), dark preconditioning resulted in decreased phenol content and polyphenol oxidase activity in the explants, controlled exudation of the phenolic compounds into the culture media, increased the survival rate of explants, and promoted bud development. Consequently, dark preconditioning can promote bud formation from explants through its effects on reducing bacterial contamination and reducing the synthesis of phenolic compounds.

To establish a tissue culture system for $H$. radiata, problems mentioned should be solved at three stages of micropropagation: introduction of elite plants into culture vessels, effective multiplication, and acclimatization. The former two stages are so essential for in vitro culture that we studied them. First, we selected various explants from greenhouse plants for tissue culture. Next, we divided floret explants to achieve more effective multiplication. Finally, we determined the effects of dark preconditioning on exudation of browning compounds and survival of explants in shoot apex cultures.

\section{Materials and Methods}

Culture media and growth environment. Habenaria radiata 'Aoba' plants were cultivated in pots in a greenhouse. Mother plants were transplanted into $200-\mathrm{mL}$ pots filled with a soil mined in Kanuma city, Japan, and grown in a greenhouse by supplying with Hyponex $(6.5 \mathrm{~N}-6.0 \mathrm{P}-19 \mathrm{~K})$ diluted 1000 times every 2 weeks. Tissue culture materials were obtained from shoot apexes and leaves at the vegetative phase and from stems, stolons, and florets at the reproductive phase. The excised parts were surface-disinfected for $5 \mathrm{~s}$ with $70 \%(\mathrm{v} / \mathrm{v})$ ethanol followed by 10 min with $10 \%$ (v/v) sodium hypochlorite solution $(0.5 \%$ active chlorine) containing one drop of Tween 20 per $100 \mathrm{~mL}$ solution and then rinsed three times with sterile distilled water.

Explants were cultured on half-strength inorganic salts and full-strength vitamins of Murashige and Skoog (1/2 MS) medium (Murashige and Skoog, 1962) containing 30

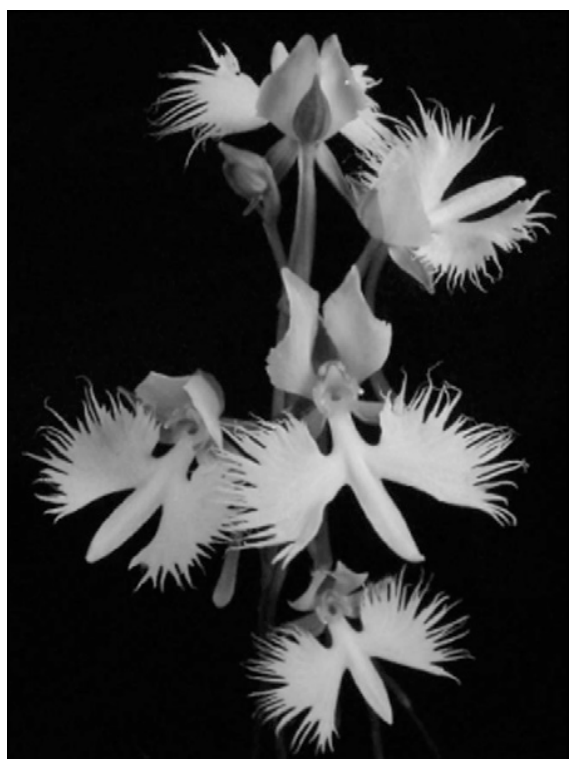

Fig. 1. Habenaria radiata (Thunb.) K. Spreng. This ornamental orchid has bird-shaped petals. 
$\mathrm{g} \cdot \mathrm{L}^{-1}$ sucrose and $8 \mathrm{~g} \cdot \mathrm{L}^{-1}$ agar (Wako Pure Chemical Industries, Ltd., Osaka, Japan) ( $\mathrm{pH}$ 5.6) supplemented with $4.44 \mu \mathrm{M} \mathrm{N^{6 }}$ benzyladenine and $0.54 \mu \mathrm{M} \alpha$-naphthaleneacetic acid. This combination and concentration of plant growth regulators were used in tissue culture of $H$. crinifera (Latha, 1999). Fifteen milliliters of medium were dispensed into $25 \mathrm{~mm} \times 120-\mathrm{mm}$ culture tubes and autoclaved at $121{ }^{\circ} \mathrm{C}$ for $15 \mathrm{~min}$. The culture environment was a 16 -h light photoperiod $(\approx 70$ $\mu \mathrm{mol} \cdot \mathrm{m}^{-2} \cdot \mathrm{s}^{-1}$ ) and $25^{\circ} \mathrm{C}$. Explants were transferred to fresh media every 8 weeks of culture.

After 8 weeks of culture, the percentage of surviving explants, the percentage of bud formation, and the number of buds per surviving explants were recorded. Data were analyzed using test of proportion difference or Fisher's least significant difference at $P<0.05$ in Excel statistics 2006 (SSRI, Tokyo, Japan).

Survival of various explants. Explants were shoot apexes $(\approx 1 \mathrm{~mm})$ and leaves $(\approx 10 \mathrm{~mm})$ from plants at the vegetative phase and flower stalks $(\approx 10 \mathrm{~mm})$, stolons $(\approx 10$ $\mathrm{mm}$ ), and florets (including inflorescence nodes, $\approx 15 \mathrm{~mm}$ ) from plants at the reproductive phase. Fifteen explants were used for each type of explant.

Division of floret. Florets at an early developmental phase ( $\approx 15$ to $20 \mathrm{~mm}$ ) were selected from inflorescences bearing one or two florets. The floret explants were divided at the ovary section into two parts: the upper portion included the perianth and the lower portion included the peduncle (Fig. 2). Twenty explants were used for each treatment.

Dark preconditioning in shoot apex culture. Green and etiolated plantlets $(\approx 15$ to $20 \mathrm{~mm}$ ) that developed from tuberous roots grown in the light (16-h photoperiod) and dark conditions for 8 weeks were used, respectively. The shoot apexes of the light and dark-preconditioned donor plantlets were excised and cultured. Ten explants with three replicates, total 30 explants, were used for each treatment.

\section{Results}

Survival of various explants. To develop an efficient tissue culture system for $H$. radiata, we first looked for suitable explants. Bacterial contamination was observed in $33 \%$ of shoot apex explants at the vegetative phase (Table 1). There was no contamination in floret explants excised from the reproductive phase plants. Shoot apexes and leaf

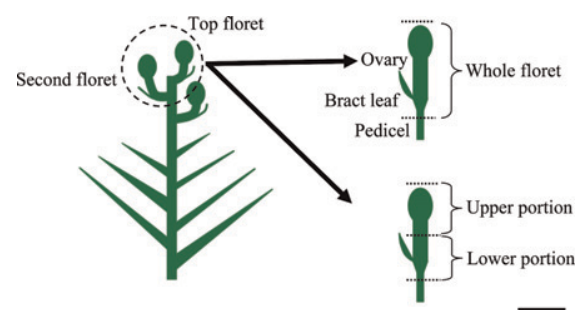

Fig. 2. Whole floret and upper and lower portions of florets used in $H$. radiata floret culture. Scale bars $=10 \mathrm{~mm}$.

Table 1. Effects of growth phase and type of explant on survival of Habenaria radiata. ${ }^{\mathrm{z}}$

\begin{tabular}{llccr}
\hline Growth phase & Explant tissue & Bacterial contamination (\%) & Browningy (\%) & Survival (\%) \\
\hline Vegetable & Shoot apex & $33 \mathrm{a}^{\mathrm{x}}$ & $33 \mathrm{bc}$ & $33 \mathrm{bc}$ \\
& Leaf & $7 \mathrm{a}$ & $80 \mathrm{a}$ & $13 \mathrm{~cd}$ \\
Reproductive & Flower stalk & $33 \mathrm{a}$ & $67 \mathrm{ab}$ & $0 \mathrm{~d}$ \\
& Stolon & $33 \mathrm{a}$ & $13 \mathrm{c}$ & $53 \mathrm{~b}$ \\
& Floret & $0 \mathrm{~b}$ & $7 \mathrm{c}$ & $93 \mathrm{a}$ \\
\hline
\end{tabular}

${ }^{\mathrm{z}}$ Data obtained after 8 weeks of culture.

${ }^{y}$ Explants exuding browning compound into media.

${ }^{x}$ Different letters indicate significant differences at $P<0.05$ by test of proportion difference.

Table 2. Effect of floret division on bud formation in floret culture of Habenaria radiata. ${ }^{\mathrm{z}}$

\begin{tabular}{lcccc}
\hline & & \multicolumn{2}{c}{ Bud formation (\%) } & \\
\cline { 2 - 4 } Portion of floret & Survival (\%) & Axillary & Adventitious & Buds per explant \\
\hline Whole & 100 & $20 \mathrm{a}$ & $0 \mathrm{c}$ & $1.3 \mathrm{~b}^{\mathrm{y}}$ \\
Upper & 100 & $0 \mathrm{~b}$ & $50 \mathrm{a}$ & $5.4 \mathrm{a}$ \\
Lower & 50 & $0 \mathrm{~b}$ & $20 \mathrm{~b}$ & $4.0 \mathrm{ab}$ \\
\hline
\end{tabular}

${ }^{\mathrm{z}}$ Data obtained after 8 weeks of culture.

y Different letters indicate significant differences at $P<0.05$ by test of proportion difference and Fisher's least significant difference.

explants at the vegetative phase showed $33 \%$ and $13 \%$ survival, respectively, after 8 weeks of culture. Among used explants at the reproductive phase, $93 \%$ of florets (including the inflorescence node) and $53 \%$ of stolon explants survived, whereas no flower stalk explants survived after 8 weeks of culture. The survival rate of floral explants was significantly high and the browning rate was low compared with other explants.

Division of florets. Because floret tissues showed the highest survival rate, we attempted to increase the multiplication rate by dividing the whole floret into upper and lower portions. Whole and upper floret explants showed the best survival rates $(100 \%)$ after 8 weeks, whereas survival of the lower portion of explants was half of it (Table 2). Axillary buds were formed in $20 \%$ of whole floret explants, whereas no such buds formed from the upper and lower floret explants. In whole floret explants, axillary buds formed at a rate of 1.3 per surviving explant (Table 2; Fig. 3A). In contrast, adventitious buds formed in 50\% from upper and 20\% from lower floret explants. The rate of adventitious bud formation was 5.4 per surviving explant in the case of upper florets and 4.0 in the lower ones (Table 2; Fig. 3B-C). No adventitious buds formed from whole floret explants, but the upper part of the floret yielded the most adventitious buds.

Dark preconditioning in shoot apex culture. Explants for shoot apex cultures were preconditioned in the dark or light to improve survival and morphogenesis and to reduce browning and bacterial contamination (Table 3). Dark preconditioning tended to decrease in bacterial contamination and browning and increase in survival explants. After 8 weeks of shoot apex culture, bud formation was significantly higher $(83 \%)$ in dark-preconditioned explants than in the light-treated ones $(60 \%)$. Most of the buds developed from the apical bud, but some formed adventitious buds at the cut surface of explants. The average rate of bud formation in surviving explants (1.1) was the same for light and dark-preconditioned explants.
After transfer to light conditions, green and robust shoots were obtained from both of the preconditioned explants. Dark preconditioning of explant material for shoot apex culture resulted in a higher multiplication efficiency and did not affect the number of buds per explant.

\section{Discussion}

Like many other orchid species, H. radiata is propagated by seeds or by division of bulbs or tuberous roots in the natural environment, although the propagation efficiency is low. Habenaria radiata has two distinct growth phases: vegetative and reproductive. After the reproductive phase, the aboveground parts of the plant die, whereas its tuberous root remains for the next generation. We selected explants from both growth phases of $H$. radiata plants to determine which part was most suitable for tissue culture. Shoot apexes from plants at the vegetative phase and floret parts from those at the reproductive phase were the most promising for tissue culture and, hence, optimal culture conditions for these explants were determined.

Axillary buds developed from whole floret explants but at a low rate (average, 1.3 per explant). Similarly, adventitious buds formed from immature floral buds and ovary parts of Paphiopedilum (Kawase, 1990). In Cymbidium goeringii, plant regeneration from floral
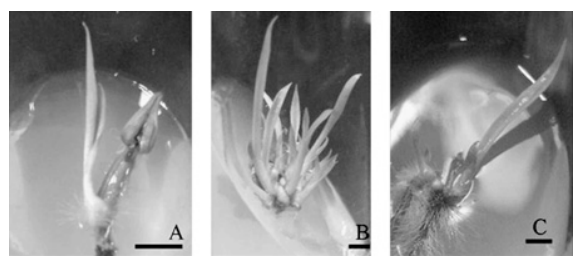

Fig. 3. Bud formation from whole (A), upper (B), and lower $(\mathbf{C})$ floret explant in $H$. radiata. Explants were cultured on 1/2 Murashige and Skoog medium containing $4.44 \mu \mathrm{M} \mathrm{N}^{6}$-benzyladenine and $0.54 \mu \mathrm{M} \alpha$-naphthaleneacetic acid for 8 weeks. Scale bars $=5 \mathrm{~mm}$. 
Table 3. Effect of preconditioning explants of field-grown Habenaria radiata on survival, bud formation, and in vitro culture of shoot apexes. ${ }^{2}$

\begin{tabular}{lccccc}
\hline Preconditioning & $\begin{array}{c}\text { Bacterial } \\
\text { contamination (\%) }\end{array}$ & $\begin{array}{c}\text { Browningy } \\
\text { explant (\%) }\end{array}$ & Survival (\%) & $\begin{array}{c}\text { Bud } \\
\text { formation (\%) }\end{array}$ & $\begin{array}{c}\text { Buds per } \\
\text { explant }\end{array}$ \\
\hline Light & 23 & 43 & 33 & 60 & 1.1 \\
$\begin{array}{l}\text { Dark } \\
\text { Proportion }\end{array}$ & 17 & 30 & 53 & 83 & 1.1 \\
$\quad$ difference & NS & NS & NS & $*$ & NS \\
\hline
\end{tabular}

${ }^{\mathrm{z}}$ Data were obtained after 8 weeks of culture.

${ }^{y}$ Explants exuding browning compound into media.

*, NS $=$ Significant at $P<0.05$, nonsignificant, respectively.

bud tissues at the apical inflorescence was also reported (Shimasaki and Uemoto, 1991). Instead of the whole floret culture method used in those studies, we devised an alternative procedure to increase bud formation in H. radiata cultures. We divided the floret into upper and lower parts. The highest rate of adventitious bud formation was observed in explants from the upper part of the floret (average, 5.4 per explant). The lower parts of the floret explants also produced buds; therefore, the multiplication efficiency of the combined upper (5.4) and lower (4.0) explants was 7.2 times higher than that of the whole explant. Bud formation using divided floret explants is thought to be suitable for multiplication of elite clones of $H$. radiata. Multiplication efficiency might be increased by the use of thin-section culture that has been reported in Doritaenopsis (Park et al., 2006), Dendrobium (Zhao et al., 2007), and Phalaenopsis (Sinha et al., 2007).

Callus, which sometimes results in an increased incidence of somaclonal variation (Evans and Sharp, 1983), was not induced in as part of this regeneration procedure of our experiment; hence, the occurrence of somaclonal variation is likely to be very low. However, there is limited availability of donor plants at the reproductive phase in the field, and it is difficult to induce plantlets to flower in culture. Therefore, axillary and adventitious buds from the shoots should be cultured repeatedly after regeneration from the floret.

Excess growth of endophytic bacteria was observed during shoot apex culture of explants from the vegetative phase in $H$. radiata as has been observed in Paphiopedilum shoot apexes (Kawase, 1990). In addition, no regenerants were obtained from leaf and stem explants because significant browning was observed with these explants. In stem culture of Paphiopedilum, explants also showed browning followed by death (Kawase, 1990). Dark preconditioning of explant material can prevent both browning and growth of endophytic bacteria in cyclamen tissue culture (Ando and Murasaki, 1983; Karam and Al-Majathoub, 2000; Murasaki and Tsurushima, 1988) and stimulated adventitious shoot regeneration and inhibited browning in apple (Wang et al., 1994), guava (Meghwal et al., 2001), and mango (Sharma and Singh, 2002). In shoot apex culture of mango, enzyme (polyphenol oxidase) activity, which is related phenolic compound metabolism, was reduced by dark preconditioning (Sharma and Singh, 2002). Consequently, promotion of bud formation in the dark- preconditioned explants might be attributed to the reduction of synthesis of phenol compounds by reduce of enzyme activity. In our study, application of dark preconditioning to shoot apex cultures increased survival and regeneration rates and decreased browning and bacterial contamination as compared with light-preconditioned explants. However, multiplication rate was low, and thus further research is necessary to optimize the method.

It was shown that florets were suitable for their introduction into culture vessels, and division of the floret into upper and lower parts promoted bud formation in H. radiata. Dark preconditioning of mother plants increased survival rate and bud formation, but multiplication rate in repeated shoot apex culture increased insufficiently for practical use so that the rate should be enhanced. With the development of acclimatization method, the tissue culture system may help to save this species from extinction and can be used to meet market and breeder demands in the future.

\section{Literature Cited}

Ando, T. and K. Murasaki. 1983. In vitro propagation of Cyclamen by the use of etiolated petioles. Tech. Bull. Fac. Chiba Univ. 32:1-5.

Arditti, J. 2008. Micropropagation of orchids. Blackwell Publishing Ltd. Malden, MA.

Environment Agency of Japan. 2000. Threatened wildlife of Japan: Red data book. Vol. 8. Japan Wildlife Research Center, Tokyo, Japan. p. 615 (in Japanese).

Evans, D.A. and W.R. Sharp. 1983. Single gene mutations in tomato plants regenerated from tissue culture. Science 221:949-951.

Karam, N.S. and M. Al-Majathoub. 2000. In vitro shoot regeneration from mature tissue of wild Cyclamen persicum. Mill. Sci. Hort. 86:323-333.

Kawase, K. 1990. Clonal propagation of Paphiopedilum by tissue culture. Bull. Exp. Farm. Kyoto Univ. 2:1-7.

Kim, K.K., J.T. Kunisaki, and Y. Sagawa. 1970. Shoot-tip culture of Dendrobiums. Amer. Orchid Soc. Bull. 39:1077-1080.

Knudson, L. 1922. Non-symbiotic germination of orchid seeds. Bot. Gaz. 73:1-25.

Latha, P.G. 1999. Micropropagation and in vitro flower induction in Habenaria crinifera Lindl. J. Orchid Soc. India 13:47-53.

Malabadi, R.B., G.S. Mulgund, and K. Nataraja. 2004. Efficient regeneration of Vanda coeru$l e a$, an endangered orchid using thidiazuron. Plant Cell Tissue Organ Cult. 76:289-293.

Matsui, T., M. Umetsu, and T. Samata. 1976. The study of tissue culture of Habenaria radiata. Japan. Soc. Hort. Sci. Autumn Meet. p. 242243 (in Japanese).

Meghwal, P.R., H.C. Sharma, A.M. Goswami, and K.N. Srivastava. 2001. Effect of stock plant etiolation on in vitro phenol exudation during culture establishment of guava (Psidium guajava L.). Indian J. Hort. 58:328-331.

Mitsukuri, K., G. Mori, M. Johkan, K.-I. Mishiba, T. Morikawa, and M. Oda. 2009. Effects of explant source and dark-preconditioning on adventitious bud formation in Neofinetia falcata $\mathrm{H}$. H. Hu in vitro. J. Jpn. Soc. Hort. Sci. (in press).

Morel, G.M. 1960. Producing virus-free Cymbidium. Amer. Orchid Soc. Bull. 29:495-497.

Murasaki, K. and H. Tsurushima. 1988. Improvement on clonal propagation of in vitro by the use of etiolated petioles. Acta Hort. 226:721-724.

Murashige, T. and F. Skoog. 1962. A revised medium for rapid growth and bioassays with tobacco tissue cultures. Physiol. Plant. 15:473-497.

Nagashima, T. 1993. Studies on development of reproductive organs in Orchidaceae with special reference to the genus Calanthe. Hort. Res. Bull. Dept. Hort. Keisen Jogakuen Junior College 26:1-85 (in Japanese).

Park, S., K.S. Shin, and K.Y. Paek. 2006. Increased ethylene and decreased phenolic compounds stimulate somatic embryo regeneration in leaf thin section cultures of Doritaenopsis hybrid. J. Plant Biol. 49:358-363.

Rasmussen, H.N. 1995. Terrestrial orchids, from seed to mycotrophic plant. Cambridge University Press, New York, NY.

Reinert, R.A. and H.C. Mohr. 1967. Propagation of Cattleya by tissue culture of lateral bud meristem. Proc. Amer. Soc. Hort. Sci. 91:664 671.

Roy, J., S. Naha, M. Majumdar, and N. Banerjee. 2007. Direct and callus-mediated protocormlike body induction from shoot-tips of Dendrobium chrysotoxum Lindl. (Orchidaceae) Plant Cell Tissue Organ Cult. 90:31-39.

Seeni, S. and P.G. Latha. 2000. In vitro multiplication and ecorehabilitation of the endangered Blue Vanda. Plant Cell Tissue Organ Cult. 61:1-8.

Sharma, R.R. and S.K. Singh. 2002. Etiolation reduces phenolic content and polyphenol oxidase activity at the pre-culture phase and in vitro exudation of phenols from mango explants. Tropical Agr. 79:94-99.

Shimasaki, K. and S. Uemoto. 1991. Rhizome induction and plantlet regeneration of Cymbidium goeringii from flower bud cultures in vitro. Plant Cell Tissue Organ Cult. 25:49-52.

Sinha, P., M.L. Hakim, and M.F. Alam. 2007. Efficient micropropagation of Phalaenopsis amabilis (L.) BL. cv. 'Cool Breeze' using inflorescence axis thin section as explants. Propagation of Ornamental Plants. 7:9-15.

Takahashi, K., H. Ichikawa, T. Ogino, T. Hatana and I. Ogiwara. 2008. Time of seed germination, infection of Orchid mycorrhizal fungi, and reintroduction of protocorms inoculated with Orchid mycorrhizal fungi and covered with gel to a habitat in Habenaria radiata (Thunb.) $\mathrm{K}$. Spreng. Hort. Res. 7:27-31 (in Japanese).

Takahashi, K., I. Ogiwara, and N. Hakoda. 2000. Seed germination of Habenaria (Pecteilis) radiata (Orchidaceae: Orchideae) in vitro. Lindleyana 15:59-63.

Tanaka, M. 1987. Studies on the clonal propagation of Phalaenopsis through in vitro culture. Mem. Fac. Agr. Kagawa Univ. 49:1-85 (in Japanese).

Wang, Q., H. Tang, Y. Quan, and G. Zhou. 1994. Phenol-induced browning and establishment of shoot-tip explants of 'Fuji' apple and 'Jinhua' pear cultured in vitro. J. Hort. Sci. 69:833839.

Zhao, P., W. Wang, F. Feng, F. Wu, Z. Yang, and W. Wang. 2007. High-frequency shoot regeneration through transverse thin cell layer culture in Dendrobium candidum Wall Ex Lindl. Plant Cell Tissue Organ Cult. 90:131-139. 